\title{
Islamic Social Reporting: From the Perspectives of Corporate Governance Strength, Media Exposure and the Characteristics of Sharia Based Companies in Indonesia and its Impact On Firm Value
}

\author{
Bayu Tri Cahya ${ }^{1}$, Amiur Nuruddin $^{2}$, Arfan Ikhsan ${ }^{3}$ \\ ${ }^{1}$ Doctoral Candidate in Islamic Economics at UIN Sumatera Utara, North Sumatra, Indonesia. \\ Lecturer at Islamic Economics Department, STAIN Kudus, Indonesia. \\ ${ }^{2}$ Professor of Islamic Economics, Faculty of Islamic Economic and Business, UIN Sumatera Utara, \\ North Sumatera, Indonesia \\ ${ }^{3}$ Lecturer at Faculty of Economic and Business, Universitas Negeri Medan, Medan, Indonesia
}

\begin{abstract}
Islamic Social Reporting (ISR) is a social reporting that involves not only a holistic expectation of the society regarding the role of the companies in the community but also a spiritual perspective. This study objective to obtain empirical evidence about the influences of corporate governance strength, media exposure, firm size, and profitability to the extent of Islamic Social Reporting and to find out the impact of ISR on firm value. To measure the extent of Islamic Social Reporting, the researchers used a checklist that had been developed based on the related rules and previous research. This study employed purposive sampling method from companies listed in Jakarta Islamic Index (JII) during 2012-2015. There are 67 companies which fulfill the criteria as the research samples. Meanwhile, the data analysis was conducted with Generalized Structured Component Analysis (GSCA). GSCA analysis is one of the Structural Equation Modellings (SEM) which is based on component (Component Based SEM). The results of this study show that corporate governance strength and profitability have positive significance on Islamic Social Reporting. However, firm size has negative significance while media exposure has no significant influence on Islamic Social Reporting. Furthermore, ISR is able to mediate the correlations of corporate governance strength, firm size, and profitability towards firm value.
\end{abstract}

Keywords: Corporate Governance Strength, Media Exposure, Company Characteristic, Islamic Social Reporting, Firm Value

\section{INTRODUCTION}

Islamic Social Reporting (ISR) is one of the ways to provide full disclosure in the context of Islam [1]. ISR presents the concepts and practices of accounting in accordance with Islamic Sharia. The establishment of ISR is expected to give a contribution to the economic and business progress, as well as the more honest and fair trade practices regardless from the international business practices. The ISR was first proposed by Haniffa [2]. It was then developed extensively by Othman et al. [1] specifically in Malaysia. According to Haniffa, there are limitations in conventional social reporting [2]. Thus, he proposes a conceptual framework of ISR based on the provisions of Islamic sharia which is not only used to assist Muslim decision makers but also to assist the companies, especially those with sharia-based, in order to fulfill the obligations towards Allah SWT and the surrounding community [2]. The ISR Index is a benchmark for the implementation of social activities in sharia companies which compiles the items of social reporting standards specified by AAOIFI (Accounting and Auditing Organization for Islamic Financial Institutions) [2]. Researchers have then elaborated the ISR Index by developing the CSR items which should be disclosed by an Islamic entity [2].Regarding the ISR concept, business entities should apply the principle of triple bottom line. The term triple bottom line was firstly popularized by John Elkington in 1997 through his book "Cannibals with Forks, the Triple Bottom Line of Twentieth Century Business" [3]. Elkington gives the view that companies which want to be sustainable should pay attention to $3 \mathrm{P}$ (profit, people, planet) [3]. In addition to the pursuit of profit, the companies must pay attention on and be involved in the fulfillment of public welfare (people), and contribute actively in protecting the environment (planet).ISR reminds the fact about the influence of Islam in accountable reporting that shows significant progress. Based on sharia, Islam has formulated a comprehensive ethic that rules how a business should be run, how an accounting should be done, and how a financial institution is managed. Islam is a significant force to influence the way Muslims conduct their public and private lives. All of these components set unique challenges for Islamic accounting and reporting [4]. Based on this phenomenon, the researchers are 
interested in examining ISR, the factors influencing the implementation of ISR, and the impact of ISR on firm value.

\section{LITERATURE REVIEW}

\subsection{Stakeholder Theory}

Friedman defines the stakeholders as follows: That group of writers comes to coalesce around particular social constructions of reality, leading to writers referring to stakeholders without being aware of relevant theoretical issues that have been raised in other literature" [5].Stakeholder theory argues that an organization has relationships with many constituent groups so that it can engender and maintain the support of these groups by considering and balancing their relevant interests [6][7][8][9]. Stakeholder theory presents a manager as the central figure of a stakeholder approach. Therefore, understanding managerial decision making might be the key to understand the balance of stakeholder interests as well as the other fundamental principles of stakeholder management [9]. This means that if a manager treats stakeholders in line with the stakeholder concept, the organization will be more successful in the long run.

\subsection{Legitimacy Theory}

The theory of legitimacy can be understood from Lindblom's statement as follows: "a condition or status which exists when an entities value system is congruent with the value system of the larger social system of which the entity is a part. When a disparity, actual or potential, exists between the two value systems, there is a threat to the entities legitimacy" [10]. The theory of legitimacy is associated with social disclosure. It suggests companies to reveal the legitimacy as they are operated in community areas. The failure to disclose the legitimacy can cause adverse implications for the company [11]. This theory encourages companies to ensure that their activities and performances are acceptable for the public. If the community is dissatisfied with the legitimacy of the operation, the community may revoke the social contract [12]. The society expectations towards the corporate behavior can be "implicit" and "explicit" [13]. The explicit form of social contract is a legal requirement while the implicit form is the community expectations which are not included in the uncodified community expectation [14]. Thus, legitimacy can be regarded as a potential benefit or source for the company to survive [15]. When there is a difference between corporate values and social values, the legitimacy of the company will be threatened. The difference between corporate values and social values, which is often called as the "legitimacy gap", can affect the company's ability to continue its business activities [14]. O'Donovan suggests that if there is a difference between the two values, firms need to evaluate their social values and adapt them to establish the social values or perceptions of the firms as legitimacy tactics [15].

\subsection{Framework}

\section{FRAMEWORK AND HYPOTHESIS}

The importance of ISR is evident as it demonstrates the accountability of the company to the community. ISR also serves a mechanism in improving transparency of business activities and conforming to the spiritual needs of the Muslims' decisions. However, what actually influence a company to do ISR has to be determined empirically. Although studies on corporate social responsibility have been extensively examined, these studies overlooked the importance of ISR. Researchers suspect that there are several factors that affect the ISR disclosure such as: corporate governance strength, media exposure, size, and profitability. Figure 1 illustrates the framework that underpins this study. The framework shows that the four factors are correlated to influence the company to do ISR and give impacts on firm value.

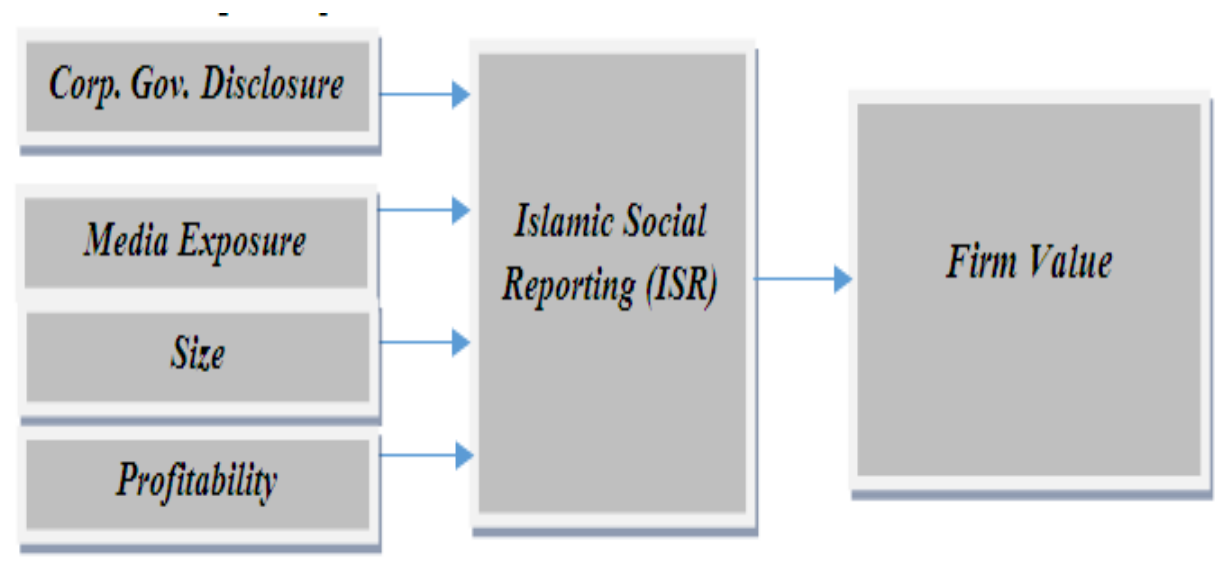

Fig 1. Conceptual Framework 


\subsection{Hypothesis \\ 3.2.1. CGS and ISR}

The effectiveness of the implementation of Islamic corporate governance is reflected in the activities of Islamic Social Reporting [16]. Arcay and Vazquez argue that analyzing individual CG mechanisms does not provide a full assessment of CG's role in promoting transparency [17]. Therefore, to reduce this problem, it is important to use the overall corporate governance score (CG). The measurements have been carried out by Wan Abdullah et al. [18] by reviewing corporate governance strength with the measurement of board size, committee audit and CEO duality. Wan Abdullah examines CG disclosure practices of Islamic Banks in the Southeast Asian countries and the Gulf Cooperation Council regions. It is revealed that Corporate Governance Strength CG has a positive and significant influence on CG disclosure. This result is consistent with many studies of board size [19][20], audit committee size [20][21] and CEO duality [22][23][24].The following hypothesis is developed:

H1: There is a positive relationship between the corporate governance strength and the disclosure of ISR.

\subsubsection{Media Exposure and ISR}

The importance of media in communicating social reporting, once expressed by Philip Kotler in his book entitled "Corporate Social Responsibility: Doing the Most Good for Your and Your Case". Kotler argues, "If you do something, but do not tell others, they may assume that you are not doing anything" [25]. According to him, the disclosure can build brand positioning, boost sales, expand market share, increase employee loyalty, reduce operational bias, and increase corporate attractiveness in the eyes of investors [26]. If Philip Kotler's disclosure above becomes a goal, the company must raise awareness to communicate the social reporting, which in this study is the disclosure of Islamic reporting. Sen, Bhattacharya and Korschun confirm that companies should be able to create optimal CSR communications [27]. Maignan and Ferell also recommend that CSR should be permeated in corporate communications [28]. Communicating corporate social activities (based on Islamic) is certainly a form of corporate responsibility of a stakeholder to convey ideas and suggestions that build criticism, as well as adaptive responses based on sharia principles. Based on the scientific description and empirical evidence of the previous research, the hypothesis is formulated as follows:

$\mathrm{H} 2$ : There is a positive relationship between the media exposure and the disclosure of ISR.

\subsubsection{Firm Size and ISR}

Ousama and Fatima find out that the size of a company would influence its decision to provide the extent of voluntary disclosure in the annual report [29]. Firm size would influence company's decisions in giving information in the annual report [2]. ISR has been significantly correlated with firm size [1]. Firm size is positively and significantly related with the level of disclosure [30][31][32][33]. Both agency theory and legitimacy theory contain arguments for a size-disclosure relationship. Based on the theories and findings of the aforementioned study, the hypothesis for this research is:

H3: There is a positive relationship between the company's size and the disclosure of ISR.

\subsubsection{Profitability and ISR}

According to Choi et al. [34], companies with good financial conditions can afford the human or financial resources required for better voluntary reporting to withstand external pressures. Luoet. al. [35] argue that companies with good financial performance have financial capability in making decisions related to the surrounding environment. Conversely, companies with poor financial performance focus more on achieving financial goals and performance improvements. According to Watts and Zimmerman [36], firms with higher profits have a tendency to conduct policy interventions. Therefore, the company will be compelled to disclose more detailed information on its annual report in order to reduce political costs and show financial performance to the public. Based on the perspective of Islam, the company should give its full disclosure regardless of the advantages or disadvantages [2]. In accordance with the empirical study examining the link between profitability and ISR, the following hypothesis is developed:

$\mathrm{H} 4$ : There is a positive relationship between the profitability and the disclosure of ISR.

\subsubsection{ISR and Firm Value}

Haniffa [2] notes the importance of ISR is obvious because it demonstrates corporate accountability to society. ISR can improve the transparency of business activities and conform the spiritual needs of Muslim's decisions. This is an excellent way to create superior corporate performance. Muslim stakeholders are expected to get information that facilitates them in making ethical Islamic decisions. Manasseh [37] finds the disclosure of social reporting is a representational expression of the corporate accountability to the society. Several studies 
have found out that social disclosure reflects the company's image (Friedman and Miles [38], Kolk [39], Adams and Zutshi [40]). CSR communication aims to build positive image to the company. In addition, Eisenegger and Schranz [41], who are concerned about the social report, states that CSR communication can maintain a good reputation.The research conducted by Umbara and Suryanawa [42] present that corporate social responsibility disclosure also shows positive impact on firm value. Legitimacy theory encourages companies to ensure that their activities and performance are acceptable to the society [43]. The acceptance of the public is expected to increase the firm value. Stakeholder theory holds that firms have to conduct social disclosure as a responsibility to the stakeholders [43]. Through CSR disclosure, the market will give a positive appreciation along with the increase in stock price of the company. Furthermore, this increase will cause the increasing on the firm value. Based on the theories and findings of the previous studies, the hypothesis of this research is:

H5: There is a positive relationship between Islamic social reporting and firm value

\subsubsection{CGS, Media Exposure, Firm Size, Profitability (as independent variables), ISR (as a mediating variable) and firm value (as a dependent variable)}

Both good governance and social responsibility aim at optimizing firm value for shareholders with regards to other stakeholders [44]. Therefore, companies need to develop a number of policies to guide the implementation of social responsibility. Good corporate governance and the aspects involved are required to ensure that all of these things get well done. Based on the theory, hypothesis for this research is:

H6: The relationship between CGS and firm value will be mediated by ISR.

Associated with media exposure, media play an active role by providing history of corporate social reporting and compiling it to describe firm value. The use of media by the company shows an increase in the company's reputation from stakeholders [45]. In reference to the theory, the following hypothesis is assumed:

H7: The relationship between media exposure and firm value will be mediated by ISR

The size of large firms leads to greater pressure and responsibility to stakeholders. When a company carries out its social responsibility as an act of social responsibility, the company's sustainability can be maintained and investors will be more interested in investing [46]. Regarding the theory, the hypothesis for this research is:

H8: The relationship between firm size and firm value will be mediated by ISR.

The company's ability to provide high expectations for future value (result) will cause the company to be highly valued by the community. The higher the profitability, the greater the disclosure of social information the company undertakes [47][48]. Based on the theory, the following hypothesis is assumed:

H9: The relationship between profitability and firm value will be mediated by ISR.

\section{METHODOLOGY}

\subsection{Data collection, Population, and Sample}

The present study belongs to quantitative research. Data include 2012-2015 annual reports registered in JII. They were obtained from Indonesia Stock Exchange (www.idx.co.id) and from Indonesian Capital Market Directory (ICMD). The population in this study involves companies listed on the Jakarta Islamic Index (JII) in the Indonesia Stock Exchange. The companies in JII were selected based on their market capitalization. The samples in this study are companies which were consistently included in JII index, published annual reports with IDR currency and were not delisted during the period of 2012-2015.

\subsection{Data measurement}

The variables were measured using data from the annual reports and the other media of the sample companies in the following manners: 1) Corporate Governance Strength was measured using combined characteristics of board size, AC size and independent chair [18], 2) Media exposure was measured using variable dichotomies, whether or not there were companies exposing Islamic social activities in the media, 3) Firm size (logSIZE) was measured using total assets of a company at the end of a reporting year [1], 4) Profitability was measured using company's profit before tax at the end of a reporting year [1]. The four variables belong to independent variables. Furthermore, The ISR level in this study consists of 41 items grouped into six topics adopted from previous research and related regulations. With regard to content analysis, each item has a value of 1 if the item is disclosed by the company, otherwise it is 0 . The disclosure rate after the assessment of the ISR index was calculated as follows: ISR disclosure $=\frac{\text { The number of items corresponding }}{\text { maximum number of scores }}$ [1][49][50]. Finally, firm value was measured using Tobin's Q Ratio. Tobin's $Q$ employed Chung and Pruitt formulation [51]: $\mathrm{Q}=\frac{M V S+D e b t}{T_{A}}$, where $\mathrm{Q}$ represents firm value, MVS is Market Value of all outstanding shares, Debt is total debts, and TA denotes Total Assets.

\subsection{Data Analysis}


The complexity of this research model was solved by structural equation model (SEM). SEM has become an established element in the methodological toolbox [52]. Researchers have embraced the advantages of SEM to test a series of interdependent relationships simultaneously [53]. Hwang and Takane [54] propose a new component-based SEM method termed generalized structured component analysis (GSCA) after Covariance-based SEM and least squares path modeling had come to the fore in the field of SEM [55][56]. GSCA represents a component-based approach to structural equation modeling. It maximizes the average or sum of explained variances of linear composites and is equivalent to an approach developed by Glang [57], which he calls "maximization of the sum of explained variances". GSCA consists of three defining elements: (1) a way to specify linear models, (2) an optimization criterion, and (3) an algorithm to obtain estimates [58]. GSCA is a part of Component-based SEM and offers global least square optimization criteria, which consistently minimize to obtain model parameter estimation. In addition, it is also equipped with overall fit model size. With regards to its benefits, researchers employed GSCA in data analysis.

\section{RESULTS AND DISCUSSION}

Descriptive statistics through content analysis was used to describe the 6 themes of the disclosures with 41 items in any year of study from 67 samples. The results are shown in Figure 2 below.

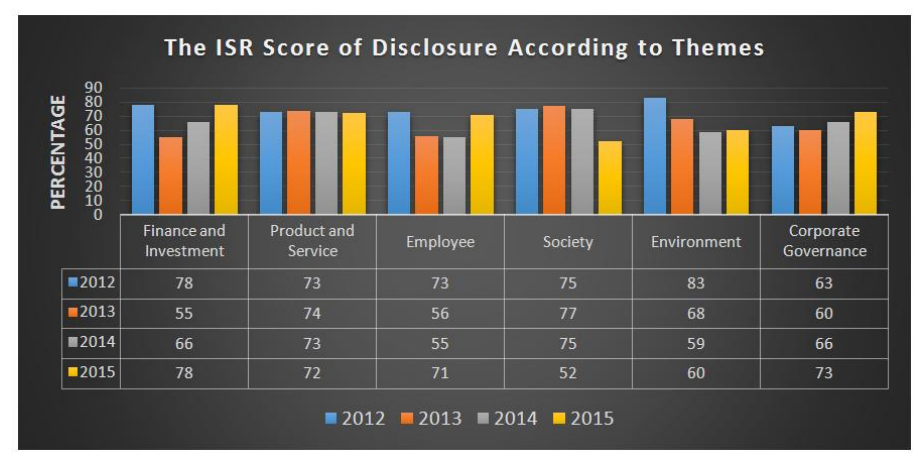

Fig. 2. ISR Score of Disclosure

The most consistent ISR theme is Product and Service. Corporate Governance theme shows a slight increase from 2012 to 2015 . It meets the expectation since the developed disclosure index studied is primarily a voluntary item under corporate social responsibility. Finance and investment theme declines slightly but ultimately restabilized, and so does the Employee theme. Meanwhile, the ISR disclosure seen from the Society and Environment themes decreases during the year 2012 to 2015. Based on the index score of ISR disclosure, there is a decrease in the value of ISR disclosure after 2012. This is possible due to the issuance of Government Regulation No. 47 of 2012 regarding Social and Environmental Responsibility [59] which complements an important guide on how social and environmental responsibility is implemented. Thus, it affects several points of social disclosure in each company. This is the turning point of social responsibility practice that was previously only seen as the company's concern for the community and its environment.

Table. 1: Structural Model

\begin{tabular}{|l|l|l|l|l|}
\hline \multicolumn{4}{|c|}{ Path Coefficients } & \multirow{2}{*}{ Conclusion } \\
\cline { 1 - 3 } & Estimate & SE & \multicolumn{1}{l|}{ CR } & \\
\hline CGS->ISR & 0.274 & 0.122 & $2.25^{*}$ & Accepted \\
\hline ME->ISR & 0.114 & 0.125 & 0.91 & Rejected \\
\hline SIZE->ISR & -0.387 & 0.183 & $2.11^{*}$ & Accepted \\
\hline PROFIT->ISR & 0.621 & 0.164 & $3.79^{*}$ & Accepted \\
\hline ISR->FV & 0.268 & 0.111 & $2.42^{*}$ & Accepted \\
\hline R square of Variable & $\begin{array}{l}\text { CGS,ME, } \\
\text { SIZE,PROFIT }\end{array}$ & $->$ & ISR & $35,4 \%$ \\
\hline & ISR & $->$ & FV & $7,2 \%$ \\
\hline
\end{tabular}

$\mathrm{CR}^{*}=$ significant at .05 level

GSCA analysis results indicate there are some accepted hypothesis (hypothesis 1,3,4,5,6,8 and 9). This is based on the $t$ value (critical ratio) which is higher than the value of $t$ table $(1,96)$.However, the mediation variableis seen from the significance of the independent variables towards the mediating variables and the mediating variables towards the dependent variables. This study proves that corporate governance strength (CGS) has a positive significant influence on Islamic Social Reporting (ISR), and therefore the effectiveness of implementation of Islamic governance is reflected and achieved in the disclosure of Islamic reporting. The determinant of Islamic governance includes corporate governance strength. This finding is consistent with the results of Abdullah's research [18] Media exposure does not have a significant influence on Islamic Social 
Reporting (ISR), meaning that the effectiveness of media exposure has not been optimally utilized by each sharia-based company in conveying activities or activities of social and sharia-based company outside disclosure in annual company reports. This finding is in accordance with the research results of Reverte [60], Anggreni and Budiasih [61]. Firm size has a negative and significant influence on Islamic Social Reporting (ISR). This means that, in this case, small companies are more likely to disclose related content of Islamic social reporting to attract or raise the confidence of related investors or stakeholders. This finding is consistent with research results of Ebiringa et al [62], Nawaiseh et al [63], Dibia and Onwuchekwa [64].Profitability has a positive and significant influence on Islamic Social Reporting (ISR). A higher level of profitability reflects an entity's ability to generate higher profits, enabling the entity to increase its social responsibility, as well as making disclosure of sharia-based social responsibility in its wider annual report. It is in accordance with the results of Othman's research [1] [65][66].The Islamic Social Reporting (ISR) has a positive and significant influence on firm value. This finding confirms that through the ISR disclosure, the market will give a positive appreciation as indicated by the increase in stock price of the company. This increase will result in an increase in firm value. This finding is consistent with research results of Umbara et al [42], Wirakusuma [43], Ahmad [67], Hill [68].Finally, ISR can mediate the relationship between corporate governance strength (CGS), firm size (size) and profitability to firm value (firm value). The relationship of ISR with media exposure to firm value (firm value), however, proved no mediation relationship.

\section{CONCLUSION}

The main objective of this study is to examine the influence of corporate governance strength, media exposure, firm size, and profitability on the extent of Islamic social reporting and its impact on firm value. Based on the results of this research, it can be concluded that 1) corporate governance strength and profitability have positive significance to influence the extent of Islamic social reporting, 2) firm size has negative significance and media exposure has no significant influence on the Islamic social reporting, and 3) ISR enables to mediate the relationship among corporate governance strength, firm size, and profit to firm value.

\section{RECOMMENDATION}

The recommendations of this research are as follows:

1. ISR disclosure should be compared to another overseas sharia-based index with strong Islamic characteristics such as Indonesia's, and therefore more ISR disclosure results in different indices or countries can be obtained.

2. The subjectivity in determining and identifying ISR index disclosure by the researcher exists since there is no standard provision that can be used as a basis or reference so that the determination of the index for indicators in the same category may be different for each researcher. Thus, to reduce the subjectivity of the researcher, there should be a discussion among experts in the same field of study or among other researchers who have examined the disclosure of the ISR index.

3. Further research can be added with a qualitative approach so that all information is disclosed. It is possible that a company has undertaken the essentials of sharia social responsibility but does not disclose it in the annual reports. In addition, further research needs to modify the model by adding the variables or path of the relationship being tracked.

\section{REFERENCES}

[1]. Rohana Othman, A. Md. Thani, dan E.K. Ghani. Determinants of Islamic Social Reporting Among Top Shariah-Approved Companies in Bursa Malaysia, Research Journal of International Studies, Vol. 12, 2009, 4-20.

[2]. R. Haniffa, Social Reporting Disclosure-An Islamic Perspective. Indonesian Management \& Accounting Research, 1 (2), 2002, 128-146.

[3]. J. Elkington. Cannibal With Work: The Triple Botoom Line in $21^{\text {st }}$ Century Business, Gabriola Island (BS: New Society Publisher. 1997).

[4]. Safarina. The Development Of Islamic Social And Environmental Reporting. Journal of Education and Social Sciences, Vol. 4 (June), 2016, 258-261.

[5]. A.L. Friedman, and S. Miles, Stakeholders: Theory and Practice (Oxford, UK: Oxford University Press, 2006).

[6]. M. B. E. Clarkson,, The Corporation and its Stakeholders: Classic and Contemporary Readings (Toronto, Canada: University of Toronto Press, 1998).

[7]. T. Beauchamp and N. Bowie, Ethical Theory and Business (Englewood Cliffs, CA: Prentice Hall, 1997).

[8]. T. M. Jones and A. C. Wicks, Convergent Stakeholder Theory, Academy of Management Review, 24, 1999, $206-221$.

[9]. Scott J. Reynolds, Frank C. Schultz, David R. Hekman, Stakeholder Theory and Managerial Decision-Making: Constraints and Implications of Balancing Stakeholder Interests, Journal of Business Ethics, 64, 2006, 285-301.

[10]. C.K. Lindblom, The Implications Of Organizational Legitimacy For Corporate Social Performance And Disclosure, Paper presented at the Critical Perspectives on Accounting Conference, New York, 1994.

[11]. Umaru M. Zubairu, O. B. Sakariyau, and Chetubo Kuta Dauda., "Social Reporting Practices Of Islamic Banks In Saudi Arabia", International Journal of Business and Social Science, 2(23), Special Issue - December 2011, 193-205.

[12]. C. Deegan, M. Rankin, and J. Tobin, "An Examination Of The Corporate Social And Environmental Disclosures Of BHP From 1983-1997: A Test Of Legitimacy Theory, Accounting, Auditing and Accountability Journal, 15 (3), 2002, $312-343$.

[13]. C. Deegan, M. Rankin and P. Voght, Firms' Disclosure Reactions to Major Social Incidents: Australian Evidence, Accounting Forum, 24 (1), 2000, 101-130 
[14]. J. Dowling and J. Pfeffer. Organizational Legitimacy: Social Values and Organization Behaviour, Pacific Sociological Review, 18 (1), 1975, 122-136.

[15]. G. O'Donovan, Environmental Disclosure in the Annual Report: Extending Them Aplicability and Predictive Power of Legitimacy Theory, Accounting, Auditing \& Accountability Journal, 15 (3), 2002, 344-371.

[16]. Indrawaty and Siti Maria Wardayati, Implementing Islamic Corporate Corporate Governance (ICG) And Islamic Social Report (ISR) in Islamic Financial Institution (IFI). Procedia-Social and Behavioral Sciences, 219, 2016, 338-343.

[17]. R. B. Arcay and F. M. Vazquez, Corporate Characteristics, Governance Rules and the Extent of Voluntary Disclosure in Spain. Advances in Accounting, 21, 2005, 299-331.

[18]. Wan Amalina Wan Abdullah, Majella Percy and Jenny Stewart, Corporate Governance Disclosure Practices of Islamic Banks: The Case of Islamic banks in the Southeast Asian and the Gulf Cooperation Council Region. Journal of International Accounting Research (JIAR) Conference, 2014, 1-33.

[19]. M. Adawi, and K. Rwegasira, Corporate Boards and Voluntary Implementation of Best Disclosure Practices in Emerging Markets: Evidence from the UAE Listed Companies in the Middle East. International Journal of Disclosure \& Governance, 8 (3), 2011, 272293.

[20]. R. C. Anderson, S. A. Mansi, and D. M. Reeb, Board Characteristics, Accounting Report Integrity, and The Cost Of Debt. Journal of Accounting and Economics, 37(3), 2004, 315-342.

[21]. N. A. A. Zaluki, and W. N. Wan Hussin, Corporate Boards, Audit Committees and Quality of Financial Disclosure in IPOs. SSRN eLibrary. 2009.

[22]. M. S. Beasley, J. V. Carcello, and D. R. Hermanson, Fraudulent Financial Reporting: 1987-1997: An Analysis of U.S. Public Companies, Committee of Sponsoring Organizations of the Treadway Commission. 1999.

[23]. W. Ben-Amar and A. Boujenoui, Factors Explaining Corporate Governance Disclosure Quality: Canadian evidence. Paper presented at the Illinois International Accounting Symposium, 2007.

[24]. J. V. Carcello and A. L. Nagy, Client size, auditor specialization and fraudulent financial reporting. Managerial Auditing Journal, 19(5), 2004, 651-668.

[25]. Kotler, Philip dan Lee, Nancy. Corporate Social Responsibilty : Doing The Most Good for Your Company Cause. (New Jersey, US: John Wiley and Sons, Inc., 2005).

[26]. U. Rusdianto. Cyber CSR: A Guide to CSR Communications on Cyber Media. (Yogyakarta, Indonesia: Graha Ilmu, 2014).

[27]. SenSankar, C. B. Bhattacharya and Daniel Korschun, The Role of Corporate Social Responsibility in Strengthening Multiple Stakeholder Relationships: A Field Experiment, Journal of the Academy of Marketing Science, 34 (2), 2006, $158-166$.

[28]. I. Maignan and O. C. Ferrell, Corporate social responsibility and marketing: an integrative framework. The Journal of the Academy of Marketing Science, 32(1), 2004, 3-19.

[29]. A. Ousama and A. Fatima, Voluntary Disclosure by Shariah Approved Companies: an Exploratory Study. Journal of Financial Reporting and Accounting, 8(1), 2010, 35-49

[30]. Khalid Alsaeed, The Association Between Firm-Specific Characteristics and Disclosure: The Case of Saudi Arabia, Managerial Auditing Journal, 21 (5), 2006, 476-496,

[31]. A. A. Mutawaa, dan A. M. Hawaidy. Disclosure level and compliance with IFRSs: An empirical investigation of Kuwaiti companies. International Business and Economics Research Journal, 9(5), 2010, 33-50.

[32]. Septi Widiawati dan Surya Raharja, Analisis Faktor-Faktor yang Mempengaruhi Islamic Social Reporting Perusahaan - Perusahaan yang Terdapat Pada Daftar Efek Syariah Tahun 2009-2011 (Engl: Analysis of Factors Affecting Islamic Social Reporting of Companies on the List of Sharia Securities Year 2009-2011), Diponegoro Journal of Accounting, 1 (2), 2012,1 -15.

[33]. Tria Karina Putri dan Etna Nur Afri Yuyetta, Faktor-Faktor yang Mempengaruhi Islamic Social Reporting Perusahaan-Perusahaan yang Terdaftar Pada Indeks Saham Syariah Indonesia (ISSI) Tahun 2011-2012 (Engl: The influence factors of Islamic Social Reporting At Companies Listed in Indeks Saham Syariah Indonesia (ISSI) year 2011-2012), Diponegoro Journal Of Accounting, 3(2), 2014, 1-9.

[34]. B. Choi, Lee Bo, Doowon and J. Psaros, an Analysis of Australian Company Carbon Emission Disclosures. Pacific Accounting Review, 25 (1), 2013, 58-79.

[35]. Le Luo, Qingliang Tang and Yi-chen Lan Lan, Comparison of Propensity for Carbon Disclosure between Developing and Developed Countries. Accounting Research Journal Vol.26 No. 1, 2013 pp. 6-34.

[36]. R. L.Watts and J.L. Zimmerman, Positive Accounting Theory. (USA: Prentice-Hall, 1986).

[37]. S. Manasseh. Study On the Level of Corporate Social Disclosure Practices In Malaysia. Master's, Universiti Sains Malaysia, 2004.

[38]. A. Friedman and S. Miles, "Social Responsible Investment and Corporate Social and Environmental Reporting in The UK: An Exploratory study", British Accounting Review, 33 (4), 2001, 523-348.

[39]. Kolk, A. (2005), "Sustainability, Accountability and Corporate Governance: Exploring Multinationals' Reporting Practices", Business Strategy and the Environment, 17 (1), 1-15.

[40]. C. A. Adam and A. Zutshi, A. "Corporate Social Responsibility: Why Businesses Should Act Responsibly and Be Accountable (part II)", Accountants Today, 2006, 24-27.

[41]. O. Ihlen, J. L. Bartlett and S. May (Eds.), Handbook of Communication and Corporate Social Responsibility (Oxford, UK: Wiley Blackwell, 2011)128-146.

[42]. D. N. D. Umbaradan I.K. Suryanawa, Pengaruh Pengungkapan Tanggung Jawab Sosial Pada Nilai Perusahaan (The Influence Of Social Responsibility Disclosure On Firm Value), E-jurnal Akuntansi Universitas Udayana 9.2, 2014, 410-424.

[43]. I G A N Bayu Darma Putra Made Gede Wirakusuma, Pengaruh Pengungkapan Corporate Social Responsibility Pada Nilai Perusahaan Dengan Profitabilitas Sebagai Pemoderasi (Engl: The Effect of Corporate Social Responsibility on Firm Value With Profitability As Moderator) E-Jurnal Akuntansi Universitas Udayana 13 (2), Nov. 2015, h. 461-475.

[44]. Moh. WahyudinZarkasyi. Good corporate governance: Pada Badan Usaha Manufaktur, Perbankan, Dan Jasa Keuangan Lainnya (Engl: Good Corporate Governance: In Manufacturing Enterprises, Banking and Other Financial Services), (Bandung, Indonesia: Alfabeta. 2008).

[45]. Ngabey Ryvandhi Ikko Wahyutama, Pengaruh Ukuran Perusahaan, Profitabilitas, Leverage, dan Media Exposure Terhadap Corporate Social Responsibility Disclosure (Engl: The Effect of Company Size, Profitability, Leverage, And Media Exposure to Corporate Social Responsibility Disclosure), Artikel Ilmiah Mahasiswa UNEJ, 2016, h. 1-8.

[46]. Mike Adams and Phillip Hardwick, an Analysis of Corporate Donations: United Kingdom Evidence, Journal of Management Studies 35(5), 1998, 641-654.

[47]. David Hackston and Marcus J. Milne, Some determinants of social and environmental disclosures in New Zealand companies, Accounting, Auditing and Accountability Journal, 9(1), 1996, 77-108. 
[48]. Ira Agustine, Pengaruh Corporate Social Responsibility Terhadap Nilai Perusahaan (Engl: The Influence of Corporate Social Responsibility to Firm Value), FINESTA, 2(1), 2014, 42-47.

[49]. R. Othman, and Azlan Md. Thani,. Islamic Social Reporting Of Listed Companies in Malaysia. The International Business and Economics Research Journal, 9, April 2010, 135-144.

[50]. Puji Lestari, Determinants of Islamic Social Reporting In Syariah Banks: Case Of Indonesia, International Journal of Business and Management Invention, 2 (10), 2013, 28-34.

[51]. Kee H. Chung and Stephen W. Pruitt, A Simple Approximation of Tobin's q, Financial Management, 23 (3), Autumn, 1994, h. 7074.

[52]. H. Baumgartner and C. Homburg, Applications of structural equation modeling in marketing and consumer research: A review. International Journal of Research in Marketing, 13(2), 1996, 139-161.

[53]. C. L. Shook, D. J. Ketchen Jr., G. T. M. Hult, and K. M. Kacmar, An assessment of the use of structural equation modeling in strategic management research. Strategic Management Journal, 25(4), 2004, 397-404.

[54]. H. Hwang and Y. Takane, Generalized structured component analysis. Psychometrika, 69(1), 2004, 81-99.

[55]. W. J. Reinartz, M. Haenlein and J. Henseler, An empirical comparison of the efficacy of covariance-based and variance based SEM. International Journal of Research in Marketing, 26 (4), 2009, 332-344.

[56]. C. Fornelland F. L. Bookstein. Two structural equation models: LISREL and PLS applied to consumer exit-voice theory. Journal of Marketing Research, 19(4), 1982, 440-452.

[57]. M. Glang, Maximierung der Summeer klärter Varianzen in linear-rekursiven Strukturgleichungs modellenmit multiplen Indikatoren: Eine Alternative zum Schätzmodus B des Partial-Least-Squares-Verfahrens (Engl: Maximization of the Sum of Explained Variances in Linear-recursive Structural Equation Models with Multiple Indicators: An Alternative to Mode B of the Partial Least Squares Approach). PhD Thesis. University of Hamburg, 1988.

[58]. Jörg Henseler, Why Generalized Structured Component Analysis Is Not Universally Preferable To Structural Equation Modeling, Journal of the Academy of Marketing Science, 40 (3), 2012, 402-413.

[59]. Indonesian Government Regulation no. 47 of 2012 on Social and Environmental Responsibility.

[60]. C. Reverte, Determinants of corporate social responsibility disclosure ratings by Spanish listed firms. Journal of Business Ethics. 88(2), 2008, 351-366.

[61]. Ni Luh Putu Mila Anggreni dan I Gusti Ayu Nyoman Budiasih, Peran Media Exposure Bagi Pasar Modal Indonesia (Engl: The Role of Media Exposure For Indonesian Capital Market), Jurnal Buletin Studi Ekonomi, 21 (1), Feb. 2016, 60-70.

[62]. O. T. Ebiringa, EmehYadirichukwu, E. E. Chigbuand Obi Joseph Ogochukwu, Effect of Firm Size and Profitability on Corporate Sosial Disclosures: The Nigerian Oil and Gas sector in Focus. British Journal of Economics, Management \& Trade 3(4): 2013, h. 563-574.

[63]. Mohammad EbrahimNawaiseh, Soliman S. Also boa and RezkAbou Zaid Youssef El-Shohnah, Influence of Firm Size and Profitability on Corporate Sosial Responsibility Disclosures by Banking Firms (CSRD): Evidence from Jordan, Journal of Applied Finance \& Banking, 5 (6), 2015, 97-111.

[64]. Ndukwe O. Dibia and John Chika Onwuchekwa, Determinants of Environmental Disclosures in Nigeria:A Case Study of Oil and Gas Companies, International Journal of Finance and Accounting, 4(3), 2015, 145-152.

[65]. Bayu Tri Cahya, Carbon Emission Disclosure: DitinjaudariMedia Exposure, Kinerja Lingkungan dan Karakteristik Perusahaan Go Public Berbasis Syariah di Indonesia (Engl; Carbon Emission Disclosure In Perpective Of Media Exposure, Environmental Performance And Syar'i Based Company Characteristic In Indonesia) Nizham, 5 (2), 2016, 170-188.

[66]. Omar, B., \& Simon, J. (2011). Corporate Aggregate Disclosure Practice in Jordan. Advance in Accounting incorporating Advance in International Accounting, 27, 166-186.

[67]. Nik Nazli Nik Ahmad, M Sulaiman, and D Siswantoro, Corporate Social Responsibility Disclosure in Malaysia: An Analysis of Annual Reports of KLSE Listed Companies. IIUM Journal of Economics and Management. 11 (1), 2003, 51-86.

[68]. Ronald Paul Hill, Thomas Ainscough, Todd Shank, and Daryl Manullang, Corporate Social Responsibility and Socially Responsible Investing: A Global Perspective, Journal of Business Ethics, 70, 2007, 165-174. 